\title{
Issues and Options for Adapting Social Protection Strategies to Climate Change Shocks in Bangladesh
}

\author{
M.A. Awal \\ Laboratory of Plant Ecology, Department of Crop Botany \\ Bangladesh Agricultural University, Mymensingh 2202, Bangladesh \\ awalma7@yahoo.com
}

\begin{abstract}
Managing the impacts of climate change requires an integrated approach of social safety net (SSN) that brings together risk-coping, mitigation and management/adaptation in the short and long terms. Furthermore such an approach needs to be implemented at national level in Bangladesh due to climate change vulnerability and widespread poverty in the population. In terms of government interventions, this means coordinating and integrating disaster risk management (DRM) programmes, SSN programmes and agricultural development interventions intended for climate change adaptation (CCA). The study has identified both ex ante and ex post mitigation/adaptation strategies with a multi-sectoral integration model with covering line ministries or departments on how SSNs can help rural households respond to more severe and more frequent climate-related shocks that they are facing. The intention is to build synergies with DRM and CCA interventions, for a continuum of responses from relief to SSNs to resilient rural development. The issues and options that addressed in the study may play an important role for designing and implementing social protection (SP) strategies with utilizing the climate funds in Bangladesh. The GO and NGO portfolios along with community based organizations and local leaders should have to work together with climate victims to deliver the most suited SP system in Bangladesh. With considering necessary avenues, some of the existing social safety nets tools like food for work (FFW) or cash for work (CFW) are to be climate proofed which not only support to the climate poor but also boost the agricultural production in the country.
\end{abstract}

Key words: Climate change, climate funds, coping, mitigation, policy, resilience, social safety net, vulnerability.

\section{INTRODUCTION}

Climate change threatens to detail progress in poverty reduction and achievement of the Millennium Development Goals (MDGs). The least developed nations, which have economies largely dependent on agriculture, limited scope of social protection (SP) and very little risk mitigation infrastructure, are the most vulnerable countries to climate change (Stern, 2006; Morton, 2007). Likewise, the poor, who live and work on marginal lands, engage in unskilled labour, and have very limited access to capital, are the most vulnerable populations to climate change. Furthermore, the risk of catastrophic weather shocks contributes to trapping poor households into chronic poverty (Barnett et al., 2008). Continuing climate change would put extra burdens on the social and economic challenges especially for the poor. Therefore, there is no time to delay for designing the befitted SP strategy to cope with climate change which is the most challenging issue now a days. 
Social protection (SP) can broadly be defined as public actions - carried out by the state or privately that enable people to deal more effectively with risk and their vulnerability to crises and changes in circumstances such as unemployment or old age, and help tackle extreme and chronic poverty (Briefing Note, 2006). The SP is concerned with preventing, managing, and overcoming situations that adversely affect people's well being. The International Labour Organisation (ILO, 1996-2014) has set out three major dimensions of social protection: (i) extending the coverage and effectiveness of social security schemes; (ii) promoting labour protection, which comprises decent conditions of work, including wages, working time and occupational safety and health, essential components of decent work; and (iii) working through dedicated programmes and activities to protect vulnerable groups.

Due to spatial geo-morphological conditions, Bangladesh is one of the worst victims of climate change in the world. Regular river floods affect 20 percent of the country, increasing up to 68 percent in extreme years. The cyclones that stroke Bangladesh coast are so frequent that on an average only 1.2-year is enough for a cyclonic hit (Awal et al., 2013). Due to the climate change effect and consequent sea-level rising, saline water intrusion occurs in the dry season as much as about $100 \mathrm{~km}$ inside the Bangladesh from the Bay of Bengal along the tributary channels and rivers that resulted about one million hectare land unsuitable for crop production. Riverbed siltation in parts of south-west Bangladesh is leading to prolonged water-logging in recent 2 to 3 decades, with consequent losses in agricultural production due to the inundation of more than 128 thousand hectare crop land (Awal, 2014). Monsoon break caused severe drought that covered a vast areas in north-western part especially high Barind tract of Bangladesh. All of those climate shocks or stresses negatively affect the agricultural production thus hampered the life and livelihood of people. Climate change is likely to increase the frequency of the aforesaid negative events to the coming days. Widespread poverty in the population has additionally compounded the situation vulnerable. Hence, no one can think the progress of Bangladesh without adopting proper SP strategy. Therefore, an integrated approach is to be designed that can sufficiently coordinate between DRM, SSN and CCA interventions (Awal, 2013).

Social safety net (SSN) is an important service in risk management where SPs are mechanisms to outspread support to those that have been adversely affected by extreme weather events. These interactions shaped by the government, communities, organized groups, or families are a key component of strategies to minimize expected losses from climate change (Naranjo and Alpizar, 2011). SSN can help households for avoiding irreversible losses from climate shocks that could ensue. Effective SSN programmes (SSNPs) should be seen as a complement to larger efforts to protect livelihoods and undertake reconstruction and recovery. Countries with existing programmess that they can scale up will be better placed to deliver SSNs after climate shocks. Alternatively, the countries that experience regular climate change shocks or stresses like Bangladesh should have to design some climate-proof or climate-resilient type of special SP framework to help vulnerable households for managing risk. Therefore, some issues and options are to be formulated before designing befitted climate resilient SP policies in Bangladesh and thus carried out this study.

\section{MATERIALS AND METHODS}

Both secondary and primary types of data have been used in the analysis. Poverty lines data of Bangladesh Statistical Survey (BBS, 2011) which calculated from the Household Income and Expenditure Survey, HIES 2010 dataset with Cost of Basic Needs (CBN) methods were used where any household with per capita expenditure below a given poverty line (2122 k.cal for moderate poor and 1805 k.cal for extreme poor) is considered as poor. With CBN method, poverty lines represent the level of per capita expenditure at which the members of a household can be expected to meet their basic needs that include food and non-food consumptions. The HIES data set was used to document the percent distribution of household with rural and urban 
areas received benefits from social safety net programmes (SSNPs) by division in 2010 survey year. Percentage of poor or non-poor climate-shocked households benefitted with SSNP was also determined from publicly accessible HIES (2010) data set. HIES data were analyzed at division level of Bangladesh. Division indicates the biggest administrative unit of government after national. There are only seven divisions in Bangladesh. Budget document on social protection scheme of Ministry of Finance, Government of Bangladesh has also been utilized for analysis. Some other secondary sources of data were collected from published and unpublished reports through personal collection and by consulting with browsing on internet.

Primary data which are mostly qualitative were collected by stakeholder consultation. Consultation meetings were conducted with secondary stakeholders like programme staffs who are working with related tasks in GO and NGOs at national, regional, district and sub-district levels. Relevant officials from line ministries like Ministry of Disaster Management and Relief (MoDMR), Ministry of Agriculture (MoA), Ministry of Environment and Forests (MoEF), Ministry of Fisheries and Livestock (MoFL), Ministry of Water Resources (MoWR), and Ministry of Local Government, Rural Development and Cooperatives (MoLGRDC) working at various climate shocks areas like cyclone, flood, salinity, water logging and drought were consulted. The consultation meetings were done with institutional managers. The government officials and NGO program staffs were contacted prior to the consultation by electronic mail or telephone explaining the objectives of the consultation. Views and opinions were also collected from primary stakeholders or rural villagers, whose livelihoods are affected by the said climate change shocks, about the services including SSN they received from both GO and NGOs portfolios.

\section{RESULTS AND DISCUSSION}

\section{Percentage of poverty and SSN beneficiary's households}

The estimates of Head Count Rate (HCR) by divisions in HIES 2010 reveal that Rangpur division has the highest incidence of poverty at about 46 percent especially due to more prevalence of extreme poor, followed by Barisal division 39 percent and Khulna division 32 percent (Figure 1). On the other hand, Chittagong division has recorded the lowest HCR of incidence of poverty at about 26 percent followed by Sylhet division 28 percent and Rajshahi division 30 percent. Generally less percentage of poor is common in urban population than that at national or rural segment across the regions except Barisal and Khulna divisions.

Highest percentage of rural households received benefits from SSNP in Khulna division at 43 percent followed by Barisal division at 37 percent in 2010 year (Figure 2). Proportion of rural households receiving benefit in Rajshahi division is the lowest at 23 percent proceeded by Chittagong division at 25 percent or by Dhaka division 28 percent in 2010 year.

\section{Distribution of SSN users by household types, programmes and regions within climate-shocked people}

Throughout the rural Bangladesh in 2010 year, about 47 percent poor households whose livelihood were affected by different type of climate change shocks received benefit from SSNP; Khulna division received the highest coverage of poor households about 73 percent while Rajshahi division received lowest about 22 percent (Figure 3).

It is evident that a remarkable percentage of climate-shocked non-poor rural households from 13 to 54 percent depending on the regions were also benefitted with SSNP (Figure 3). Among the climate-shocked social safety net users in rural Bangladesh on the other hand, a larger portion of non-poor households from 40 to 75 percent depending on the divisions have also 
been benefitted with SSNP (Figure 4). Highest percentage of non-poor SSN users was noticed in Barisal division (75 percent) followed by Sylhet division (73 percent) or Rajshahi division (71 percent). If the SSN benefit was distributed exclusively to the poor households instead of those non-poor one it was possible to cover another 22 percent rural climate-shocked poor households and hence the SSN coverage to poor (currently 47 percent) can be elevated to 69 percent nationally. Similarly, such figure can be raised to about 40, 67, 63, 107, 31, 58 and 52 percent for Barisal, Chittagong, Dhaka, Khulna, Rajshahi, Rangpur and Sylhet divisions, respectively. If the SSN coverage elevates to such way the elevated coverage would also deficit except for Khulna division although the operation of such type of safety net distribution exclusively oriented to poor is very difficult. Therefore real selection of SSN users is important in Bangladesh through which at least one-fifth number of poor climate-stressed households those who are currently benefitted with safety net programmes, can be brought under social protection scheme without increasing any budget of the government.
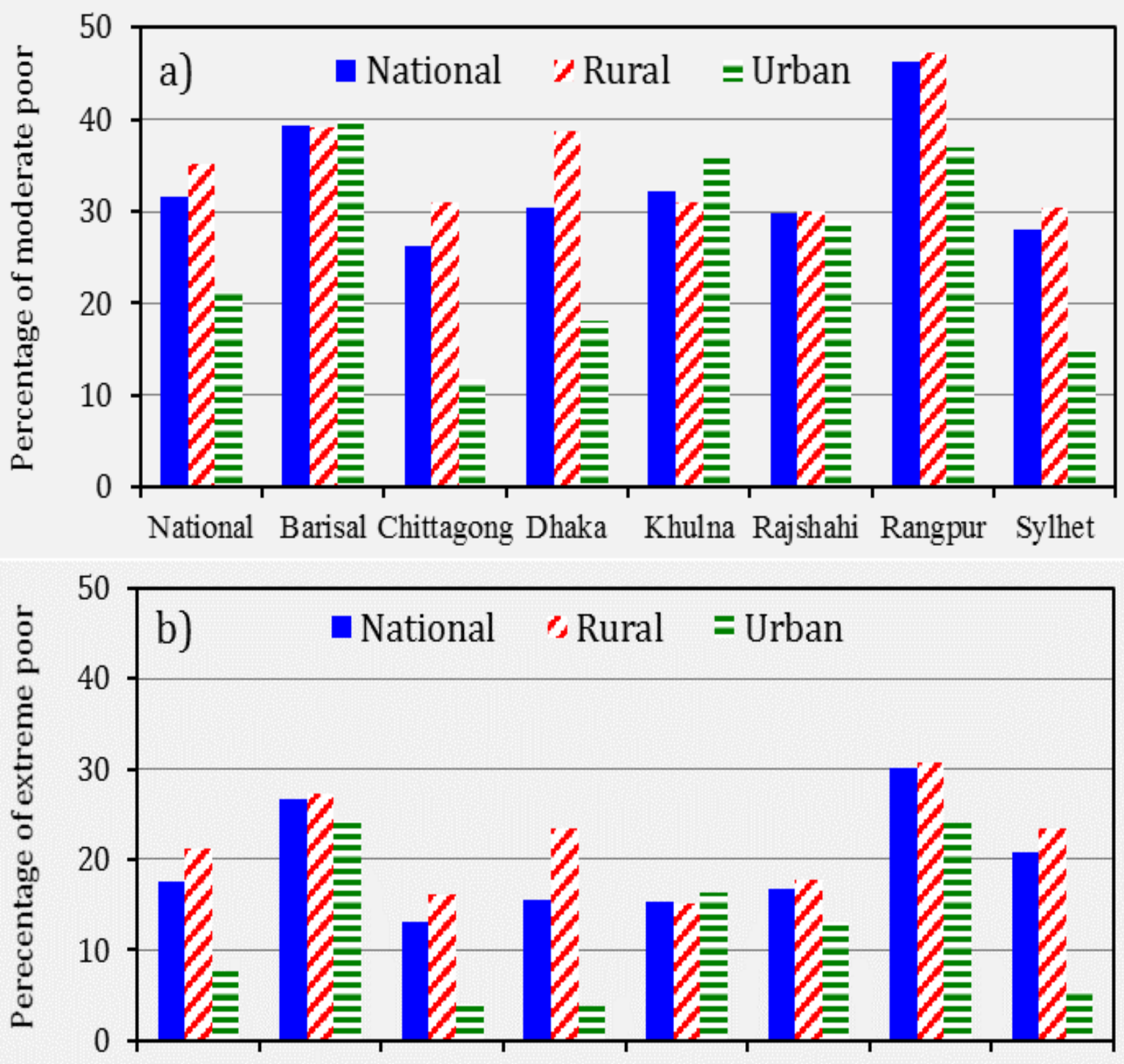

National Barisal Chittagong Dhaka Khulna Rajshahi Rangpur Sylhet

Division

Figure 1. Incidence of poverty (HCR) by CBN method by administrative division of Bangladesh (BBS, 2011). 


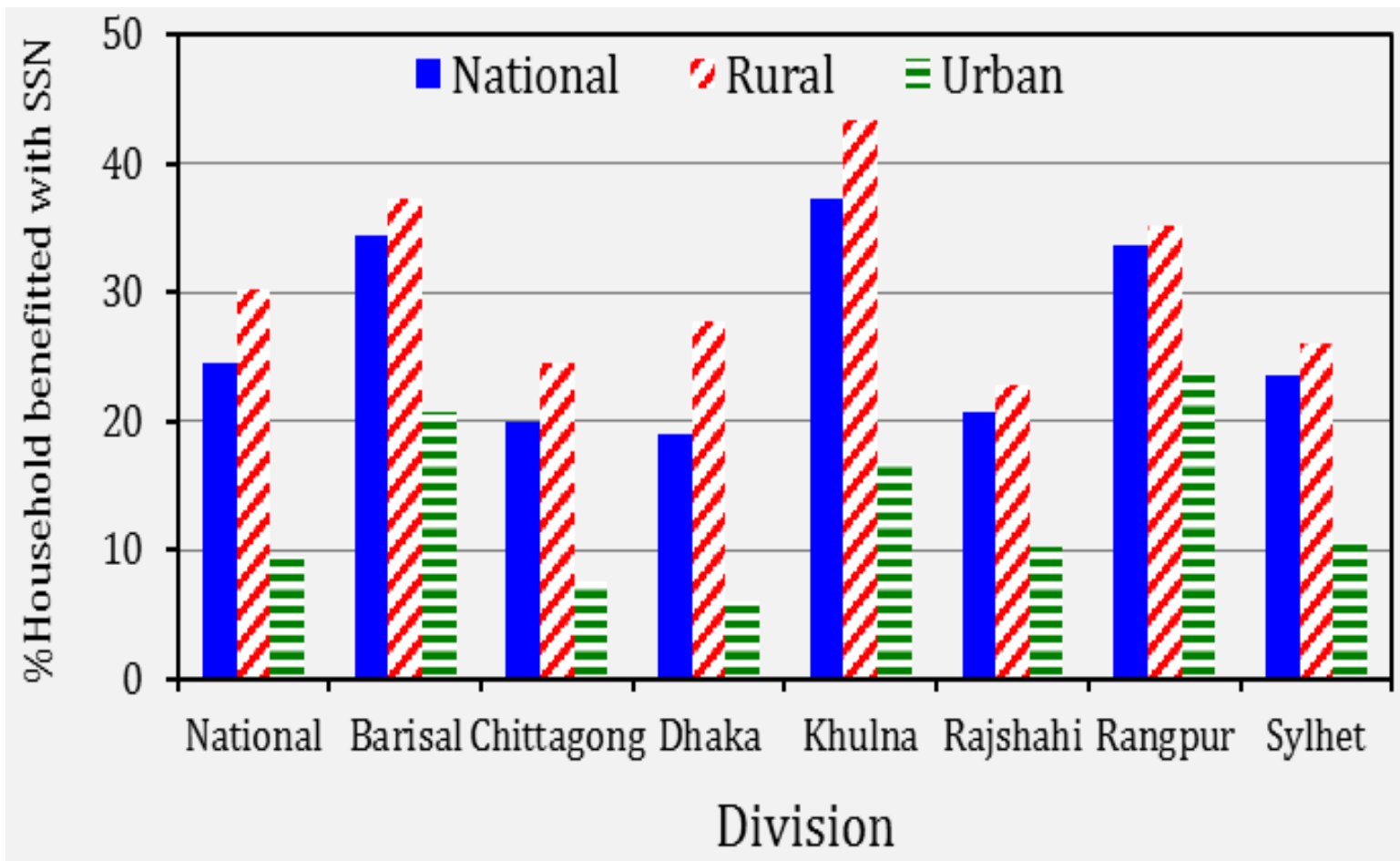

Figure 2. Percent distribution of household received benefits from SSNPs by division in 2010 (BBS, 2011).

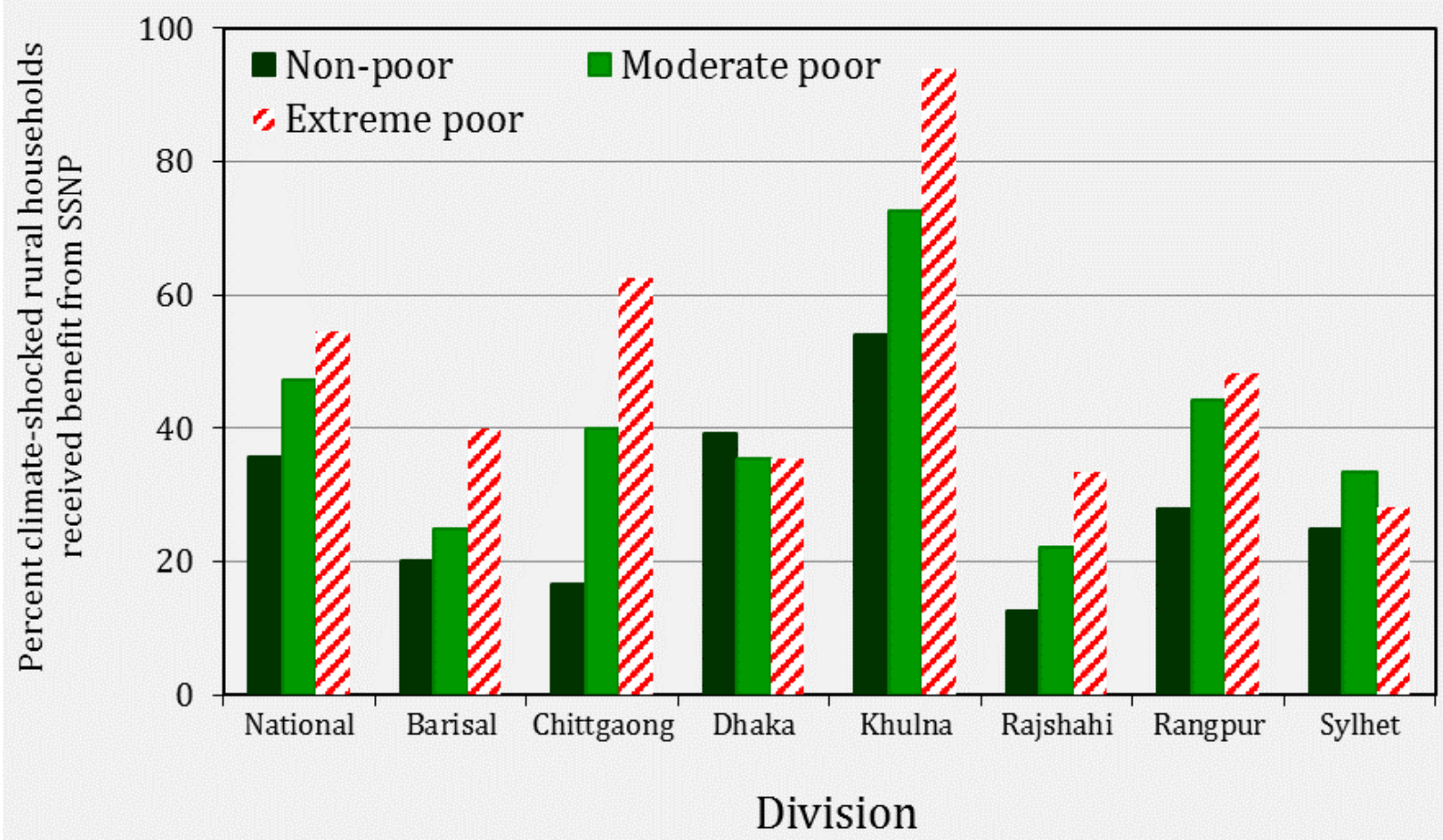

Figure 3. Percentage of poor or non-poor climate-shocked rural households benefitted with SSNPs (HIES, 2010). 


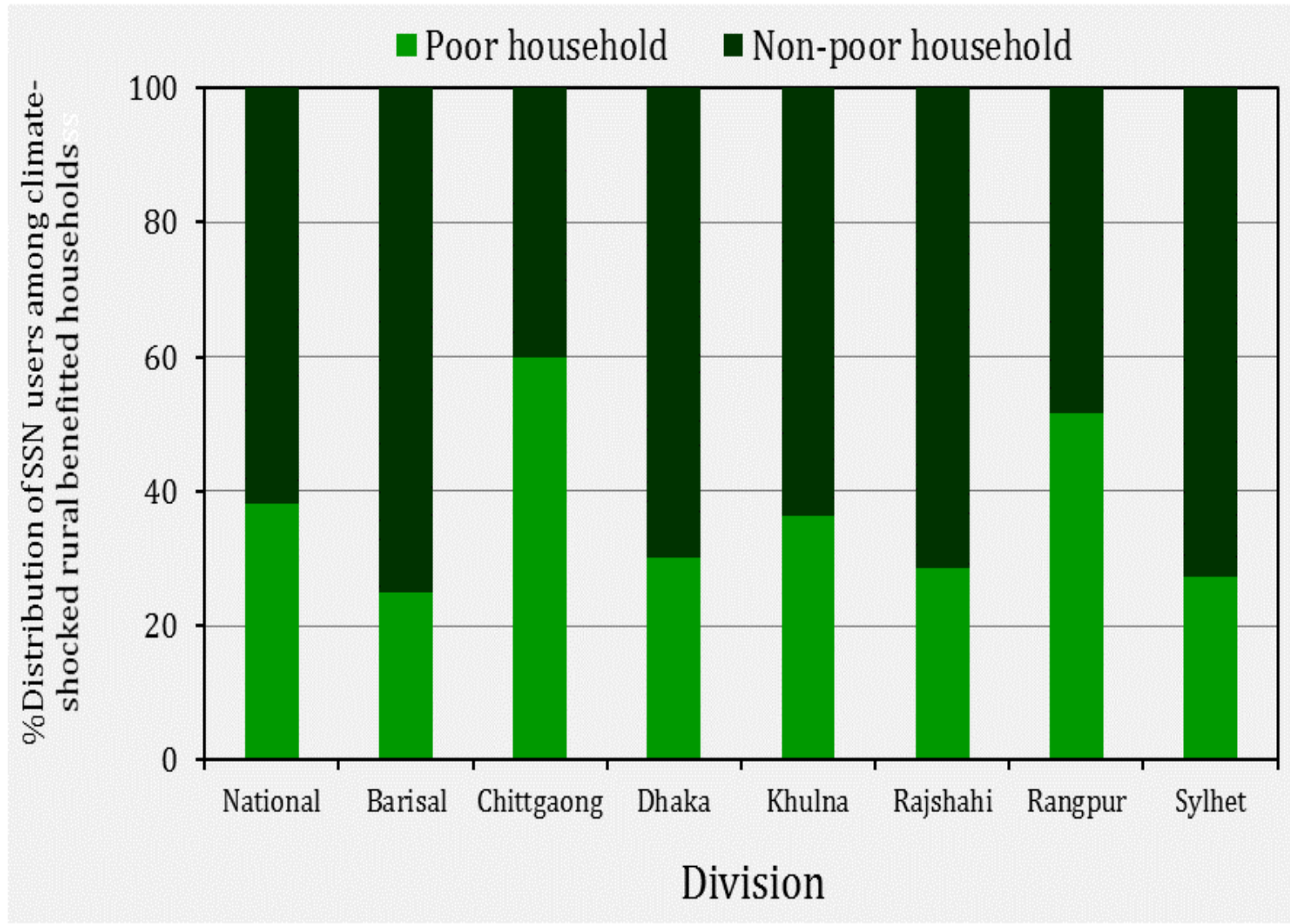

Figure 4. Distribution of climate-shocked rural SSN users within poor and non-poor households (HIES, 2010).

\section{Public spending on social safety net services in Bangladesh}

Although the budget for SSN from FY 2009-10 to FY 2012-13 has been increased about 36 percent (Figure 5a) however its allocation to total national budget and Gross Domestic Product (GDP) is gradually being declined since FY 2010-10 (Figure 5b). Approximately 14 percent of the national budget (4 FY's mean) corresponding to 2.18 percent GDP is being utilized for operating the SSN (Figure 5b) through a varieties of programme.

Weigand and Grosh (2008) reported that mean spending in World Bank countries on safety nets was 1.9 percent of GDP and median spending was 1.4 percent of GDP. For about half of those countries, spending falls between 1 and 2 percent of GDP although some variation is apparent. Bosnia and Herzegovina, Pakistan, and Tajikistan, for example, spend considerably less than a percent of GDP, while spending on social safety nets in Ethiopia and Malawi is nearly 4.5 percent of GDP because international aid is counted, but will be more like 0.5 percent if only domestically financed spending were considered. Different opinions are also available for example, Business Recorder (2012) stated that India spends over 2 percent of its GDP on its core safety net programmes. The overall government expenditure on safety net in Asia and the Pacific stands at around 5 percent with wide regional swings. While in Pakistan, the social safety net programmes are fragmented with very limited coverage. Public spending is a mere 2.4 percent of GDP which lacks adequate targeting. So the amount spending on social safety net in Bangladesh seems reasonable as compared to the neighbour or some other countries in the World. However, the intervention should be adapted on the beneficiary selection which is to be oriented to exclusively poor household with some targeted programmes. 


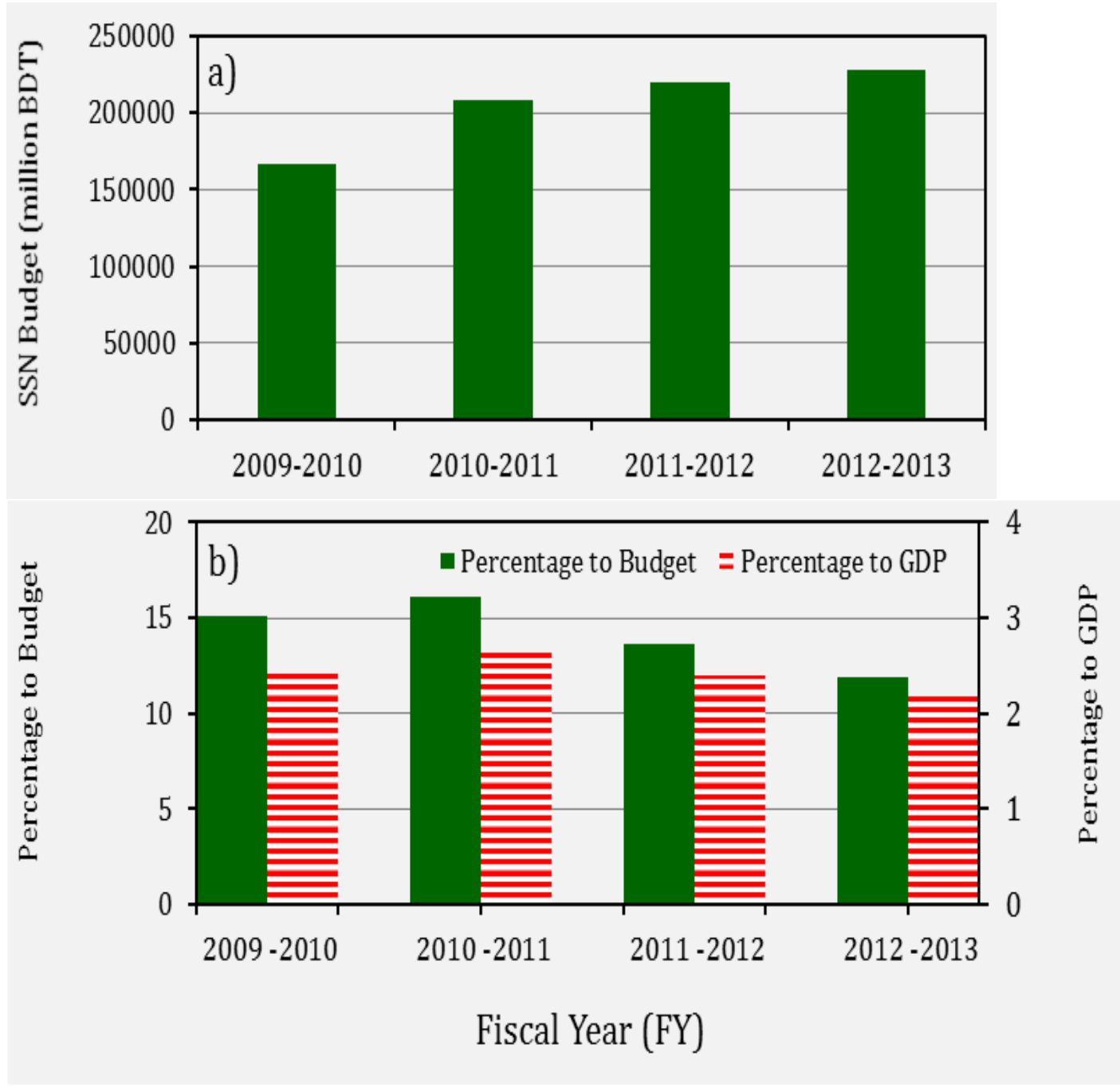

Figure 5. Budget of social safety net (a) and its allocation to national budget and GDP (b). Source: Budget document, Ministry of Finance, Government of Bangladesh.

\section{Financing on climate change ${ }^{1}$ in Bangladesh}

Since the immediate action on the BCCSAP $(2008,2009)^{2}$ was so crucial, the Government of Bangladesh (GoB) initiated with national funds, rather than wait for finance from the

${ }^{1}$ What is Climate Finance? Climate finance was born of the 'polluter pays principle' - the idea that industrialized countries have contributed the most to global warming and should therefore compensate developing nations for the costs they face as a result of climate change. In 2009, leaders of developed countries pledged US $\$ 30$ billion in fast-start finance to help developing countries build resilience to the effects of climate change and cut back on their own carbon emissions. That funding, it is hoped, will be scaled up to US $\$ 100$ billion per year by 2020 (Climate Governance, 2012).

2 Bangladesh Climate Change Strategy and Action Plan (BCCSAP; prepared on 2008 and revised it in 2009) which is expected to be the blue print for subsequent integration of climate change issues to six broad areas of intervention like (i) food security, social protection and health; (ii) comprehensive disaster management; (iii) infrastructure; (iv) research and knowledge management; (v) mitigation and low carbon development; and (vi) capacity building and institutional strengthening into the mainstream planning process. A Climate Change Unit (CCU) has been established at the Department of Environment and Forests to coordinate the overall activities on climate change in the country. 
international community. At the same time, since the costs involved were far greater than the government could provide on its own, the country appealed to the international community for assistance and donations. Recognising the uncertainties and inadequacies of international adaptation finance from both multilateral and bilateral sources, the GoB decided to establish the Bangladesh Climate Change Trust Fund (BCCTF) based on revenue from the national budget, within a legal mandate by the Climate Change Trust Act passed in Parliament in 2010. At the same time, an alternate Bangladesh Climate Change Resilient Fund (BCCRF - formerly known as the Multi Donor Trust Fund, or MDTF) was created to pool funds from the Development Partner (DP) countries to support Bangladesh in implementing the BCCSAP. The two funds have differing governance and management arrangements, but both are meant to support the implementation of the BCCSAP (Ahsan, 2014).

\section{a) The Bangladesh Climate Change Trust Fund (BCCTF)}

BCCTF, a block budgetary allocation in the form of an endowment by the GoB that has been established with the revenue budget. Since 2009-10 up to the current 2014-15 fiscal year, a total of BDT2900 crore (BDT = Bangladesh Taka) has been allocated to BCCTF. About $66 \%$ of this amount was spent on the implementation of projects/programmes prioritized in the BCCSAP, and 34\% was used as a 'fixed deposit' for tackling emergency situation and generating additional money to implement the BCCSAP. The interest accrued on the 34 percent fixed deposit was also spent on project implementation. As of April 2013, 282 projects have been undertaken with an estimated cost of BDT1997.04 crore. Different ministries, departments and agencies of the government are implementing 219 projects while 63 projects are being implemented by NGOs. Among the government projects, 31 have already been completed. The financial management of NGO projects has been vested to Palli Karma- Sahayak Foundation (PKSF). So far, BDT25 crore has been allocated to PKSF (BCCT, 2014).

The BCCTF was used to finance public sector and non-government projects mainly related to agricultural research, mitigation, adaptation and disaster risk reduction, and knowledge generation. A Climate Change Unit, established under the Ministry of Environment and Forests (MoEF), serves as a secretariat for the BCCTF. The Unit is headed by the Secretary of the MoEF, and coordinated by an additional secretary of the ministry. It is responsible for ensuring efficient implementation of the activities funded by the BCCTF.

\section{b) The Bangladesh Climate Change Resilient Fund (BCCRF)}

Bangladesh Climate Change Resilience Fund (BCCRF) is a coordinated financing mechanism by the GoB, DPs and the World Bank (WB) to address the impacts of climate change. The fund was established in May 2010 with financial support from Denmark, European Union, Sweden and United Kingdom. Switzerland, Australia and United States subsequently joined the fund. This mechanism is enabling the government to channel in over US\$188 million grant funds to millions of Bangladeshis to build their resilience to the effects of climate change. The GoB leads on the management and implementation of BCCRF (BCCRF, 2013). Examples of some projects under implementation are Multipurpose Cyclone Shelter Construction Project (US\$25 m), Climate Resilient Participatory Afforestation and Reforestation Project (US\$33.8 m), Community Climate Change Project (US\$12.5 m), Solar Irrigation Expansion Project (US\$25 m) etc.

An amount of $90 \%$ of the total amount would be spent by different ministries ('on-budget' window for public sector projects) plus charged by the World Bank (2-3\%) while the rest $10 \%$ ('off-budget' window for civil society and private sector projects) would be managed by PKSF to support initiatives taken by NGOs to implement community-driven interventions that build resilience to climate change impacts. 


\section{c) Other climate funds}

(i) Climate Investment Funds (CIF): The CIFs are a unique pair of financing instruments designed to support low-carbon and climate-resilient development through scaled-up financing channeled through ADB, the African Development Bank, European Bank for Reconstruction and Development, Inter-American Development Bank, and World Bank Group. Since 2008, fourteen contributor countries have pledged a total of $\$ 8$ billion to the CIF, which is expected to leverage an additional $\$ 55$ billion from other sources. The CIF allocates financing through four funding windows: Clean Technology Fund (CTF; $\$ 5.5$ billion) for middle-income countries, Forest Investment Program (FIP; \$639 million) for developing countries, Pilot Program for Climate Resilience (PPCR; $\$ 1.3$ billion) for developing countries, and Scaling Up Renewable Energy in Low Income Countries Program (SREP; \$551 million) (CIF, 2014).

The CIF provides 48 developing and middle income countries with urgently needed resources to mitigate and manage the challenges of climate change and reduce their greenhouse gas emissions. US $\$ 110$ million in grants (45\%) and near-zero interest credits (55\%) from the PPCR will enable Bangladesh to make strategic investments in critical areas of climate resilience planning and implementation in a manner consistent with its poverty reduction and sustainable development objectives (CIF, 2014).

(ii) Green Climate Fund (GCF): The Green Climate Fund (GCF) was adopted as a financial mechanism of the UN Framework Convention on Climate Change (UNFCCC) at the end of 2011 in Durban. The GCF is intended to be the centrepiece of Long Term Financing under the UNFCCC, which has set itself a goal of raising $\$ 100$ billion per year by 2020 . It aims to make an ambitious contribution to attaining the mitigation and adaptation goals of the international community. Over time it is expected to become the main multilateral financing mechanism to support climate action in developing countries (GCF, 2014). Bangladesh has been nominated by the least developed countries (LDCs) to the GCF to help the country fighting global warming. It is committed that the GCF is to be worked fully from 2014. Bangladesh needs a National Designated Authority as a supra coordination body in respect of climate planning, to attract International Climate Finance including GCF (NGO News Report, 2013).

(iii) Bilateral Funds (BF): Lengthy procedure of multi-donor fund arrangement and disbursement has pushed the country to think about the bilateral fund. DPs have different types of interventions in Bangladesh that are driven by their own national policies. The US government issues grants to NGOs through a number of different agencies; however, USAID is its primary distributor. USAID has a 5-year Global Climate and Development Strategy that is effective through 2016. The initiative operates through three objectives and three priority areas of action: Adaptation, Mitigation and Integration; and Adaptation, Clean Energy, and Sustainable Landscapes, respectively. Mostly through USAID, the US government provides climate change assistance to some 50 developing countries, particularly those most vulnerable to climate change (Fundsforngos, 2013a). USAID in Bangladesh spends US\$100 million/year is one of their largest development assistance program in the world.

(iv) Multilateral Funds (MF): There are many more initiatives with International Financial Institutions (IFIs) including the WB, ADB, UNFCC, UNDP, UNEP, European Commission etc those who finance to various issues of climate change (Fundsforngos, 2013b). The GoB received grants and loans from different multilateral sources including small grant for MoEF from the grant and loan for Strategic Programme for Climate Resilience (SPCR) from PPCR of the CIF of the WB, multi-donor grant for Comprehensive Disaster Management Programme (CDMP) managed by United Nations Development Programme (UNDP), loan from ADB etc. 


\section{Utilisation of climate funds}

There are so many channels to finance climate change related programmes and projects in Bangladesh. Most of these programmes operating without adequate transparency, accountability and appropriate participation of people, and civil and political society (Shamsuddoha and Bijoy, 2012). Relative success amongst the different funding routes should be carefully monitored so that good practice can be shared and further investments channelled in the most effective ways. By this time some questions have been raised regarding the use of climate funds that the spending is not found in transparent way (Daily Ittefaq, 2013). An audit of the funds spent so far is required to ascertain the value of money and prevention of resource waste in various ways including corruption. Transparency and accountability in spending climate funds would help the country to attract foreign funds in future to combat climate change (Daily Star, 2012).

For proper implementation of all type of climate funds a single national mechanism which leads the planning process, financial mobilization, programme and project development, fund disbursement and monitoring and evaluation is essential (http://www.tibangladesh.org/files/CFG-Assesment_Working_Paper_english.pdf; accessed on December 17, 2014). Policy coherence couldn't be ensured unless a single national mechanism is in place.

Either the GoB should introduce this or the donor agencies should put this as a mandatory process for all countries to follow towards receiving any form of financial and/or technical support from them (Mukta, Z.H., unpublished). More capacities to develop robust programmes and spend money effectively are needed. There is also need to coordinate the related tasks more effectively. Project evaluation must be needed transparently.

\section{What institutional constraints exist for getting ministries to coordinate on SSNs in the context of climate change in Bangladesh?}

Bangladesh saw the greatest momentum for integration among the SSN, DRM and CCA interventions, making it a good entry point into the region, for building a coalition of adapting social protection partners and thereby spread learning and good practice to other countries (Arnall et al., 2010). The country is also quite advanced in terms of setting up systems of SSN, but they are not always reliable or as prepared for disasters as might be expected. Some institutional constraints are existed to getting ministries to coordinate on SSNs in the context of climate change. The general SSN services of Government of Bangladesh (GoB) are primarily poverty response while only a little effort is rendered to climate change issue. Additionally, all poor are not benefitted with SSN services while a segment of non-poor are also benefitted from that.

The Ministry of Disaster Management and Relief (MoDMR) is the primary office in Bangladesh coordinating government disaster management efforts. Department of Disaster Management (DDM) serves as a technical arm to the MoDMR, overseeing and coordinating all disaster (including climate shocks) management activities from nation to grassroots level and maintaining liaison with government agencies, donors, NGOs to ensure cooperation and coordination. The DDM is also responsible for designing and channelling the services related to VGF, TR, GR and FFW programmes. The Department has also a unique institution, Comprehensive Disaster Management Programme (CDMP) to play flagship role to response to any disaster. The Climate Change Cell (CCC) is one of the core programme components of CDMP established as a unit of the Department of Environment (DoE) of the Ministry of Environment and Forests (MoEF) which acts as a central focus for the government's climate change related work that has made significant contributions to increasing the nation's capacity to respond proactively to disasters. 
Ministry of Food plays an important role as its duties in disaster management as: (i) incorporate DRR (disaster risk reduction) considerations into the national food security of the government; (ii) consider current and future disaster risks in the estimation of food stock requirements; (iii) consider current and future risks while designing new storage facilities; (iv) issue necessary orders with the instruction to the relevant departments to ensure implementation of the risk reduction policies.

The administration and implementation of SSN projects like Food for Work programme which operated in dry agricultural slack season, is highly centralized where local governments submit project proposals that are reviewed and supervised by national-level technical departments like departments of roads, agriculture, and so on. A long time is therefore needed for descending the decision to the local level through a series of departments which delays to start the project works.

The GoB's post disaster response is to deliver immediate food assistance along with other basic needs to the climate victims. In addition GoB serves the climate stressed people at different times especially rainy or flood seasons with a few SSN tools named Vulnerable Group Feeding (VGF), Test Relief (TR), Gratuitous Relief (GR) etc which are also primarily poverty response not the climate change. Eventually the relief materials are distributed to the climate victims through the union council under the Ministry of Local Government, Rural Development and Cooperatives (MoLGRDC). Like other public agendas, the money related to safety net services is to be released from Ministry of Finance (MoFin) which lengthening the distribution of safety net services.

On disaster therefore, the decisions on safety net services (VGF and TR goods, for example) are to be passed a long channel from concerned department of centre of country to union council through district and sub-district offices. Since the associated institutions belong to the different ministries, ultimate success on disaster response becomes limited. Eventually most SSN programmes are implemented through local government like union council or LGED, unwanted intervention at the various institutions especially at sub-district level may appear as another constraint for ensuring better safety net services to the climate poor. It appeared during the stakeholder consultation that involvement of multi-institutions in the safety net delivery system is the main institutional constraint for getting ministries to coordinate on SSNs in the context of climate change in Bangladesh.

\section{Drawing implication for designing and implementing social safety net in Bangladesh}

Climate change poses the versatile threats to Bangladesh. Firstly, it may be expected to increase the unpredictability of extreme weather events like floods and cyclones. Secondly, there are likely to be other changes such as ecosystem degradation due to slow onset climate stresses, such as sea-level rising, water logging, salinity, drought etc which reduce the availability of food, fuel, water and other basic needs. Thirdly, bad impacts on livelihoods, which together reduce the capacities of poor households to cope with disaster risks. Although the Government of Bangladesh is operating over a hundred of SSN programmes for better graduation of livelihood of poor and vulnerable segments of people. Overall the entire effort seems satisfactory, but with a closer look it couldn't reach to a distinct mark due to the following reasons: (i) mistakenly inclusions of non-poor households in the programmes, therefore it is not possible to consider many real poor, (ii) major services are intended to poverty response rather than the real climate victims, (iii) many programmes have an insufficient number of beneficiaries as compared to size of poor, (iv) insufficient number of days in workfare programmes in a year, etc. Policy makers may often express their satisfaction with operating a larger number of SSNPs but most tools don't really serve the climate poor rather some robust climate proofed ones could have actually hurt them. Nevertheless the minimisation of institutional barrier due to multi-administrative 
layers for getting ministries on course of a disaster, and unwanted intervention from administration for selecting real climate victims may bring some additional successes.

Climate hazards seriously disrupt crop production which distorts poor's livelihood through insufficient production of local food and their unemployment situation as their livelihood is primarily agrarian. Improved agricultural production system may reverse the situation substantially through reducing disaster losses and by building the resilience of communities to disasters. Climate funds may explore the befitted production systems through operating adaptive research projects on real climate issues in real places. Eventually, adaptive capacity of climate poor dwellers against climate shocks and stresses should have to improve that can ensure proper resiliency of the communities. Year-round workfare programmes like food for work or cash for work (now operating in slack dry agricultural season only) with engaging climate victims from chronically poor households can strongly be considered in this regard which may ensure the income flow to climate victims (Subbarao, 2003). Bangladesh has a long history and experience with public workfare programmes to fight against chronic poverty but the activity is dropped to a minimum level during the long rainy season. Considering the socioeconomic aspects of Bangladesh, an opportunity for widening the areas of workfare programme round the year can be explored from global arena, like cleaning of infrastructures; construction, rehabilitation and repair of irrigation and drainage canals, water supply and sewerage systems; renovation of traditional water bodies; construction/rehabilitation of basic health care facilities; improved land productivity, soil fertility restoration/increased land availability/improved market infrastructures (access); forestry management/reforestation; environment protection; drought proofing activities; social services; information technology projects etc (del Ninno and Subbarao, 2009).

The overall success cannot be achieved until the entire paradigm is reached to a proper integration of SSN, DRM and CCA interventions. The concept of Adapting Social Protection (ASP) is a more climate-resilient livelihood approach which is considered as a good starting point assumed that combining the components of those domains can improve the efficiency of interventions, lowering vulnerability and increasing resilience (Davies et al., 2009).

The term resilience is increasingly used in the development community to indicate a proactive asset/livelihood approach to SSN, DRM, CCA and food security that specifically targets poor and at-risk individuals, households and communities (Siegel, 2011). The role of ex-ante and ex-post SSN services as well as the multi-sectoral coordination among the line ministries such as the Ministry of Disaster Management and Relief (MoDMR), Ministry of Agriculture (MoA), Ministry of Environment and Forests (MoEF), Ministry of Fisheries and Livestock (MoFL), Ministry of Water Resources (MoWR), and Ministry of Local Government, Rural Development and Cooperatives (MoLGRDC) for adopting resiliency due to climate change shocks and stresses in rural Bangladesh can be outlined in Figure 6.

In addition to the existing vulnerability, climate shocks fall poor to additional vulnerable condition due to loss of their income sources and destroy of houses. Community as a whole may also suffer due to disruption of infrastructures and institutions. Hence the suffering of shocked people might be reduced with providing structural supports like cyclone or flood protection centre followed by transfer of ex post SSN services with food, water, medicine, money and other basic needs. For providing better services to the different categories of households, following options can be considered aftermath a disaster:

- For saving life, landless/micro holding ultra poor are to be supported with food with other basic needs and employment opportunities (e.g. food for work or cash for work);

- Small households are to be benefitted with food, cash supports and other basic needs for saving their life and starting their own income generation activities; 
- Medium households are to be benefitted with cash/bank loan with minimum service charge, agricultural extension services and necessary input supports for encouraging them to return back into agricultural production.

Proper CCA can be achieved through promoting the adaptive capacity of the climate affected households with creating income generation activities on local needs. Some additional risks can also be transferred through asset formation or adopting insurance scheme. With deploying possible all sorts of ex ante and ex post strategies the vulnerable community might be more resilient or more adaptive to avert climate change risks, and thus CCA is ensured. However, proper importance should be given on the adaptive researches of climate change issues through utilizing the climate funds, thus befitted strategies would come out for risk mitigation. The GO and NGO portfolios along with community based organizations and local leaders should have to work together for delivering the most suited SP to climate victims in Bangladesh.

\section{a) Measures against climate shocks/sensitivity}

The role of measures for managing the sudden climate change shocks or disasters (i.e. sensitivity) like flood of cyclone events can be addressed as:

Ex ante measures:

- A good number of multi-tier cyclone (with coastal design) and flood protection centres can be built allowing enough provision to save the livestock, food materials and important household assets in addition to people during disasters. Other than the disaster time, those cyclone and flood protection centres might be used as educational institutes like schools and colleges or other business centres etc;

- Disaster preparedness training and related other services should be provided to the people of climatically vulnerable areas;

- Rural roads or embankments, public ponds and other infrastructures should properly be rehabilitated, and maintained with planting monocotyledons trees like palmyra palm, date palm, coconut, betel nut etc on their slopes. Public safety net instruments like food for work or cash for work can be deployed to that works;

- Income generation activities should be enhanced rather than relief. Because unconditional relief aid reduces the resiliency of climate-stressed people.

\section{Ex post measures:}

- During or aftermath of a disaster, an integrated safety net delivery system in coordination with GO and NGO bodies, national and international donors should be developed which widens the number of beneficiary through eliminating the repetition of same beneficiary in the different programmes;

- In addition to food aid the affected household should be provided with safe drinking water, health facilities, cloths and other basic needs;

- Recovery activities should be done immediately after a disaster. Affected households should be benefitted with bank loans with zero or minimum service charges for recovering their houses or other productive assets like livestock;

- Rehabilitation activities should be prioritized to agricultural activities with providing necessary subsidy like seeds/seedlings, fertilizers, pesticides, cash incentives, and improved extension services etc and rebuilding of infrastructures. 


\section{Adaptive Researches on Climate Change Issue}

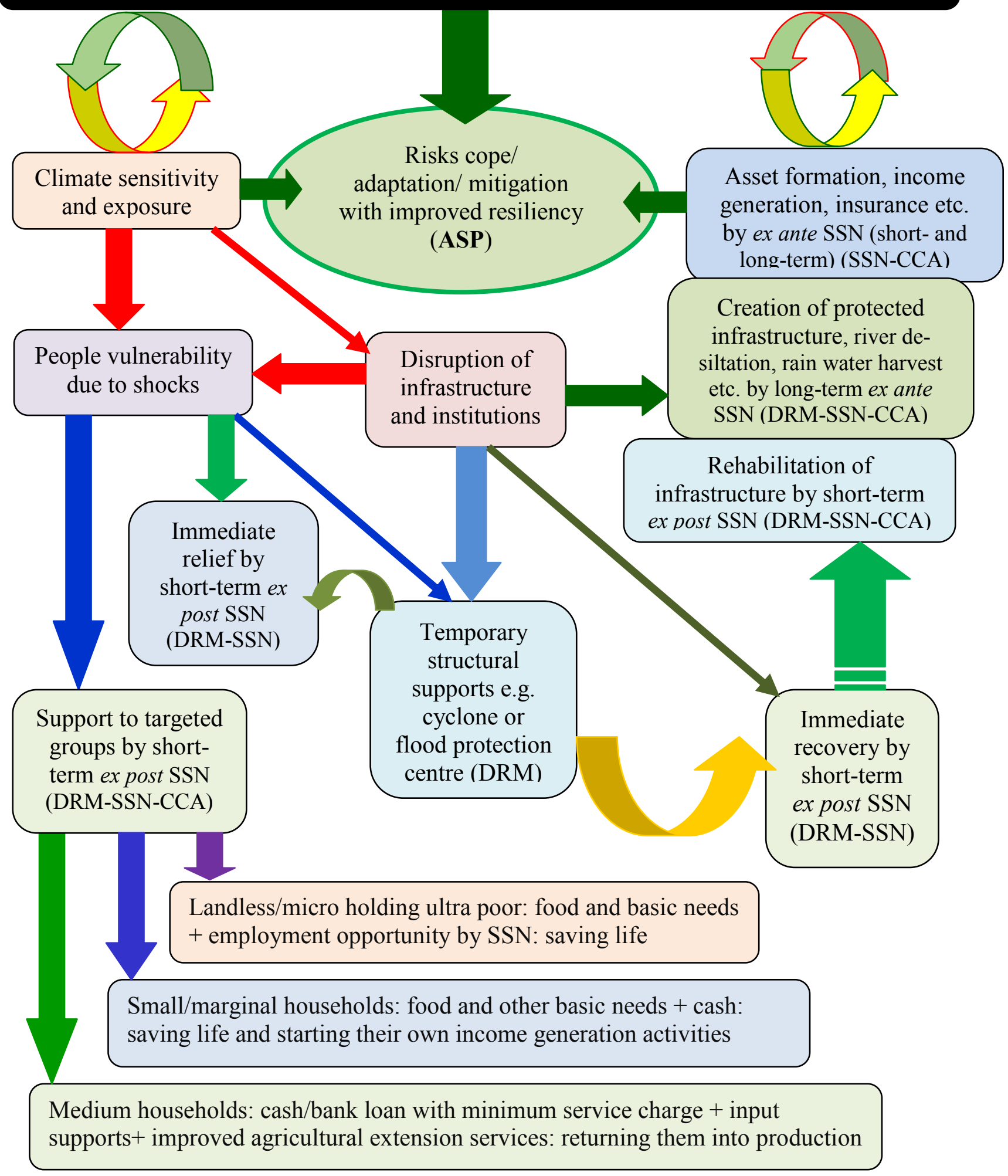

Figure 6. Proposed conceptual model/framework for integrating CCA, SSN and DRM interventions through multi-sectoral planning in rural Bangladesh. Level of integration for an effort is shown within parenthesis where, SSN: social safety net, DRM: disaster risk management, CCA: climate change adaptation and finally, ASP: adaptive social protection. 


\section{b) Measures against climate stresses/exposure}

The climate change stresses (i.e. exposures) like global warming, sea-level rising, water logging, salinity, drought etc have far reaching consequences to agriculture, life and livelihood for any nation of the world. The managements of such slow onset but long-term consequences are more critical than the sudden shocks or disasters. Therefore, initiation of new adaptive researches and continuation of on-going projects on national or regional climate change agendas for adapting the agricultural enterprises to gradual changes of climatic parameters may play some decisive roles. There are some options for developing a climate-resilient agricultural intervention like:

- Exploring the new avenues of adaptive researches on climate change agendas with proper utilising the climate funds like BCCTF, RCCRF, CIF, GCF, BF, MF etc;

- Wide dissemination of output of adaptive researches like salinity/submergence/heat/drought tolerant crop varieties along with production technology in climate stressed areas through seminars, symposia, mass media, seed fairs etc, and their proper extension to the end users i.e. climate stressed producers or growers;

- Changing of cropping patterns with land/water zoning and extension the suitable production technology. For example cultivation of rice can be suggested in mild salinity affected areas whereas shrimp or crab in extreme saline zone like exposed coast of Shyamnagar Upazila (an upazila means a sub-district), Satkhira District;

- Deploy more workforces round the year from chronically poor households with FFW or CFW programme to agricultural development activities like rain or flood water harvest, construction of mini-pond, irrigation channel/river de-siltation etc for efficient utilization of salinity and drought prone or water-logged land in crop production purposes. The programme can also be extended to tree plantation with their proper nursing in road side, barren or deforested land etc;

- Design and implementation of the productive safety net programmes like cash transfer to climate-stressed growers.

\section{CONCLUSION}

The issues and options that are addressed in this study may play an important role for designing and implementing social protection to climate change shocks in Bangladesh. GO and NGO portfolios along with community based organizations and local leaders should have to work together with climate victims to deliver the most suited social protection system in Bangladesh. With considering necessary avenues, some of the existing social safety nets tools like food for work or cash for work are to be climate proofed which not only support to the climate poor but also boost the agricultural production in the country.

\section{ACKNOWLEDGMENT}

This paper is based on a study financed under the Research Grants Scheme (RGS) of the National Food Policy Capacity Strengthening Programme (NFPCSP). The purpose of the RGS was to assist in improving research and dialogue within civil society so as to inform and enrich the implementation of the National Food Policy. The NFPCSP is implemented by the Food and Agriculture Organization of the United Nations (FAO) and the Food Planning and Monitoring Unit (FPMU), Ministry of Food with the financial support of EU and USAID. 
The designation and presentation of material in this publication do not imply the expression of any opinion whatsoever on the part of FAO nor of the NFPCSP, Government of Bangladesh, EU or USAID and reflects the sole opinions and views of the author who is fully responsible for the contents, findings and recommendations of this report.

\section{References}

Ahsan, M.D., 2014. Bangladesh Climate Change Trust: Latest Scenario of Activities and Developments. The Guardian. URL: http://www.theguardianbd.com/bangladesh-climatechange-trust-latest-scenario-of-activities-and-developments/; accessed on September $22,2014$.

Arnall, A., Oswald, K., Davies, M., Mitchell, T. and Coirolo, C., 2010. Adaptive social protection: mapping the evidence and policy context in the agriculture sector in south Asia. IDS Working Paper \#345. Centre for Social Protection. Institute of Development Studies at the University of Sussex Brighton BN1 9RE UK.

Awal, M.A., 2013. Social safety net, disaster risk management and climate change adaptation: examining their integration potential in Bangladesh. International Journal of Sociology Study, 1(4): 62-72.

Awal, M.A., 2014. Water logging in south-western coastal region of Bangladesh: local adaptation and policy options. Science Postprint, 1(1): e00038. doi:10.14340/spp.2014.12A0001.

Awal, M.A. et al., 2013. Adapting social safety net programs to climate change shocks: issues and options for Bangladesh. Final Report of the NFPCSP's sponsored Research Project. Submitted to Food and Agriculture Organization of the United Nations (FAO), Dhaka.

Barnett, B., Barrett, C. and Skees, J., 2008. Poverty traps and index-based risk transfer products. World Development, 36: 1766-1785.

BBS, 2011. Report of the Household Income and Expenditure Survey 2010. Bangladesh Bureau of Statistics, Statistics Division, Ministry of Planning (MoP), Government of the People's Republic of Bangladesh.

BCCRF, 2013. Bangladesh Climate Change Resilience Fund. URL: http://bccrf-bd.org/; accessed on September 20, 2014.

BCCSAP, 2008. Bangladesh Climate Change Strategy and Action Plan. Ministry of Environment and Forests (MoEF), Government of the People's Republic of Bangladesh.

BCCSAP, 2009. Bangladesh Climate Change Strategy and Action Plan. Ministry of Environment and Forests (MoEF), Government of the People's Republic of Bangladesh.

BCCT, 2014. Climate Change Trust Fund (CCTF). Bangladesh Climate Change Trust (BCCT), Ministry of Environment and Forests, GoB. URL: http://www.bcct.gov.bd/index.php/trust-fund; accessed on September 20, 2014.

Briefing Note, 2006. Social protection in poor countries. A DFID practice paper. SOCIAL PROTECTION BRIEFING NOTE SERIES, NUMBER 1. URL: http://www.gsdrc.org/docs/open/SP17.pdf; accessed on December 12, 2014.

Business Recorder, 2012. Pakistan's Premier Financial Daily. November 28, 2012. BR RESEARCH. 
CIF (Climate Investment Funds), 2014. About the Climate Investment Funds. ADB, European Bank, Inter-American Development Bank and WB Groups. URL: https://www.climateinvestmentfunds.org/cif/aboutus; accessed on September 20, 2014.

Climate Governance, 2012. Monitoring climate money: top-down meets bottom-up. Transparency International. URL:http://www.transparency.org/news/feature/monitoring_climate_money_top_down _meets_bottom_up; accessed on September 20, 2014.

Daily Ittefaq, 2013. Question to spend climate funds: Donor's Outlook. The Daily Ittefaq, a leading National Bangla Daily Newspaper of Bangladesh. Published on Sunday, February $3,2013$.

Daily Star, 2012. Climate change: fund use must be transparent. The Daily Star, a leading National English Daily Newspaper of Bangladesh. Published on Tuesday, April 10, 2012.

Davies, M., Guenther, B., Leavy, J., Mitchell, T. and Tanner, T., 2009. Climate change adaptation, disaster risk reduction and social protection: complementary roles in agriculture and rural growth? Working Paper 320, Brighton, UK: IDS.

del Ninno, C. and Subbarao, K., 2009. How to make public works work: a review of the experiences.

Fundsforngos, 2013a. Bilateral Funds for Climate Change. FUNDSFORNGOS, LLC, 866 United Nations Plaza, Suite 437, New York, NY 10017 USA. URL: http://www.fundsforngos.org/free-resources-for-ngos/bilateral-funds-climate-change/; accessed on September 20, 2014.

Fundsforngos, 2013b. Multilateral Funds for Climate Change. FUNDSFORNGOS, LLC, USA. URL: http://www.fundsforngos.org/free-resources-for-ngos/multilateral-funds-climatechange/; accessed on September 20, 2014.

GCF, 2014. Green Climate Fund. URL: http://gcfund.net/home.html; accessed on September 20, 2014.

HIES, 2010. Household Income and Expenditure Survey. Bangladesh Bureau of Statistics, Statistics Division, Ministry of Planning, Government of the People's Republic of Bangladesh.

ILO, 1996-2014. Social Protection. International Labour Organization (ILO). URL: http://ilo.org/global/about-the-ilo/decent-work-agenda/social-protection/lang-en/index.htm; accessed on December 12, 2014.

Morton, J.F., 2007. The impact of climate change on smallholder and subsistence agriculture. Proceedings of the National Academies of Sciences, 104: 19680-19685.

Naranjo, M.A. and Alpizar, F., 2011. The role safety nets as part of adaptation strategies to climate change in Central America. Policy Brief. The EfD (Environment for Development) Center in Central America.

NGO News Report, 2013. Bangladesh needs a national designated authority to attract international climate finance. URL: http://ngonewsbd.com/civil-society-rights-grouptransparency-inclusive-supra-coordination-body-climate-finance-planning/; accessed on September 20, 2014. 
Shamsuddoha, M. and Bijoy, M.R., 2012. Climate Finance in Bangladesh: Context and Overview, Network on Climate Change, Bangladesh (NCC, B), Dhaka, 2012.

Siegel, P.B., 2011. 'No regrets' approach to decision-making in a changing climate: toward adaptive social protection and spatially enabled governance. Background paper prepared for World Resources Institute for the 2010. World resources report on decision-making for climate change. URL: www.worldresourcesreport.org/responses/noregretsapproach-decision-making-changing climate-toward-adaptive-social-protection-a; accessed on August 4, 2011.

Stern, N., 2006. Stern review report on the economics of climate change, Cambridge: Cambridge University Press.

Subbarao, K., 2003. Systemic shocks and social protection: role and effectiveness of public works programs. Social Safety Net Primer Series. Social Protection Unit, Human Development Network, the World Bank.

Weigand, C. and Grosh, M., 2008. Levels and patterns of safety net spending in developing and transition countries. Social Protection Discussion Papers from the World Bank. Paper number 44857. URL: http://econpapers.repec.org/paper/wbkhdnspu/44857.htm; accessed on December 16, 2014. 